\title{
Crop Evapotranspiration and Irrigation Scheduling in Blueberry
}

\author{
David R. Bryla \\ U.S. Department of Agriculture, Agricultural Research Service
}

USA

\section{Introduction}

There are currently 139,000 ha of blueberry worldwide, including 66,000 ha of highbush [comprises northern highbush (Vaccinium corymbosum), southern highbush (Vaccinium sp.), and rabbiteye ( $V$. virgatum formerly $V$. asheii) cultivars] and 73,000 ha of lowbush blueberry ( $V$. angustifolium) (Strik \& Yarborough, 2005; USHBC, 2009). The majority of the fruit is produced in North and South America and Europe, although production is increasing in Asia and Africa. No matter where blueberry is grown, proper irrigation management is critical for producing high yields and good fruit quality. Even within a few days without rain or irrigation, water stress develops quickly in blueberry, reducing photosynthesis and leading to less growth and fruit production. Over irrigation, however, reduces blueberry root function, increases soil erosion and nutrient leaching, and enhances the probability of developing crown and root rot infection by soil pathogens such as Phytophthora. Developing accurate irrigation regimes requires knowledge of both the timing and amount of water needed to replenish any lost by crop transpiration and soil evaporation.

In this chapter, I discuss the importance of irrigation on growth and development in blueberry and examine its relationship to plant water relations. Identified are symptoms of water stress, the most critical stages of water limitations, and various techniques used to monitor plant water status throughout the growing season. I then discuss irrigation scheduling for blueberry, including procedures used to calculate crop evapotranspiration and estimate total irrigation requirements, and finally present recent data on the best methods to apply irrigation. Information is provided on the response of blueberry to not only different irrigation systems and configurations but also of when and where to apply the water. Throughout the chapter, irrigation methods and practices are related to other factors essential to consider when growing blueberries, including interactions with field establishment, planting bed management, nitrogen nutrition, and root disease.

\section{Growth and development of blueberry in relation to irrigation}

\subsection{Seasonal patterns of root and shoot growth}

The typical pattern of growth and development of highbush blueberry over an annual cycle are illustrated in Fig. 1. According to Abbott \& Gough (1987), new root production begins in early spring when soils reach a temperature threshold of approximately $8{ }^{\circ} \mathrm{C}$. This is then followed by leaf bud swell. Root growth peaks at two times during the growing season. The 
first peak occurs in late-spring and the second, the largest, occurs after harvest. Interestingly, both peaks occur when soil temperatures are at 14 to $18{ }^{\circ} \mathrm{C}$, strongly suggesting that root growth is regulated, at least in part, by soil temperature in blueberry. Similar soil temperature optimums for root growth were found in other temperate fruit species such as apple (Nightingale, 1935; Rogers, 1939) and peach (Nightingale, 1935). Shoot growth, by comparison, appears less controlled by temperature and more controlled by availability of plant resources. Shoot growth first peaks after the initial peak in root growth but then declines when fruit maturation begins. During fruit maturation in mid-summer, fruit provide a highly competitive sink for carbohydrates and nutrients, considerably reducing the availability of resources to other parts of the plant. Because of the decline in vegetative growth during this period, fruit removal is often recommended during the first 2 years of orchard establishment in order to increase growth of new plantings and improve yields during following years (Strik \& Buller, 2005). Aside from the beginning and end of the growing season, shoot and root growth are lowest just prior to fruit harvest (Fig. 1). Once harvest is complete, a second flush of new shoots and roots occur. Often, more than

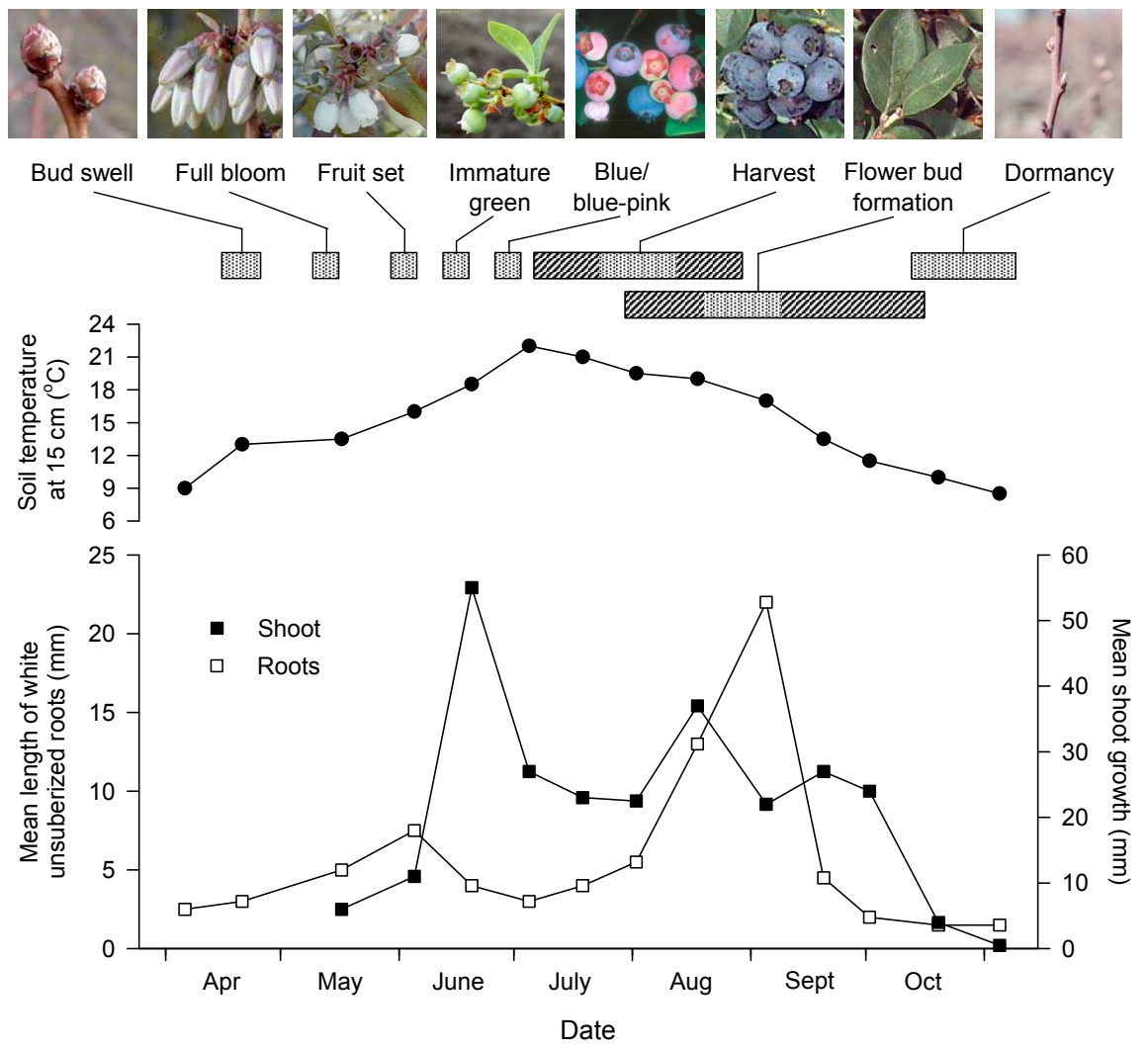

Fig. 1. Elongation of white unsuberized roots in relation to shoot growth, soil temperature, and stage of development of highbush blueberry plants. Adapted from Abbott and Gough (1987). 
one flush of shoots can happen after harvest, although the number of flushes varies depending on cultivar and cultural practices. Flower bud induction overlaps with fruit harvest and coincides with the second peak in root growth. Shoot and most root growth finally ceases in late-autumn as the plant enters dormancy and does not resume until the following spring.

\subsection{Flowering and fruit development}

Bud break and bloom in blueberry occur in early spring when evaporative demand is usually low and leaf size is still small. Thus, aside from any water needed for fertilizer application, irrigation requirements prior to pollination and fruit set are minimal and often unnecessary, depending on spring precipitation. However, once the fruit are set and the canopy develops, sufficient rain or irrigation becomes critical. It is at this early stage of fruit development, often referred to as Stage I, that rapid cell division takes place in the fruit (Fig. 2). Cell division is very sensitive to water stress, and if diminished, will reduce the size of the berries at harvest. Following this stage, the berries enter Stage II, a period of slow growth for several weeks followed by a final stage of rapid cell expansion and fruit ripening

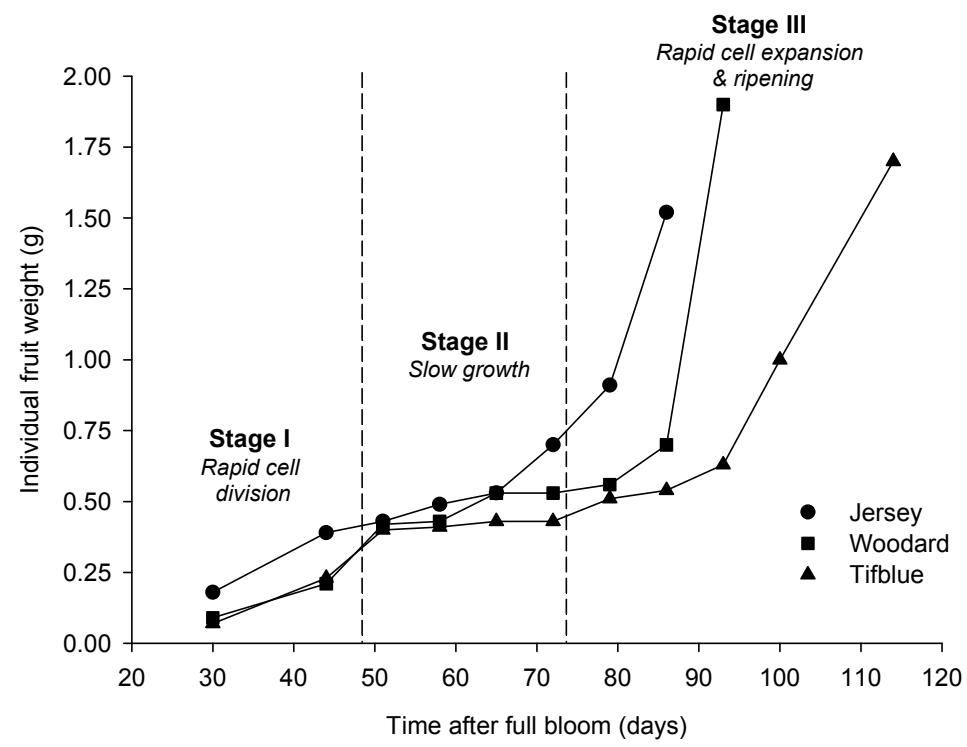

Fig. 2. Individual fruit weight of 'Jersey' highbush blueberry and 'Woodard' and Tifblue' rabitteye blueberries. Adapted from Tamada (2002).

(Fig. 2). Numerous studies on grape and tree fruit crops, which display similar double sigmoidal patterns of fruit growth as blueberry, indicate that effects of moderate water stress during this middle lag phase period has little effect on the size of the fruit at harvest. Theoretically, water stress at this stage should also have minimal effects on fruit size in blueberry. Abbott \& Gough (1987), however, indicate that it is precisely at this stage of berry development that vegetative growth is at its maximum peak (Fig. 1). Blueberry is dependent 
on new wood for production of fruit the following year. Conceivably, any water stress occurring during this peak in shoot production could limit production of new canes for next year's crop.

Irrigation during Stage III is also critical and is perhaps the most sensitive period to water stress, as any water limitations at this point will reduce cell expansion and berry size and therefore have a large impact on yield. Mingeau et al. (2001) examined the effects of water deficits at various phenological stages in 'Bluecrop' blueberry and found that even moderate water stress (i.e., enough to reduce transpiration by 35\%) during the final stage of fruit growth and ripening strongly influenced yield by reducing both mean fruit weight and fruit diameter. They also found that water stress after harvest reduced the number of flower buds. Flower bud induction occurs in mid- to late-summer in most cultivars and overlaps with late fruit development (Fig. 1). Thus, in addition to reducing yield of the current year's crop, water stress during the final stage of berry development will also reduce the number of flowers and fruit produced the following year.

Nutrient requirements also vary over the growing season but do not necessarily correlate with water demands. This difference is an important consideration when using irrigation to fertigate (Bryla et al., 2010). Unlike water, the largest demands for many nutrients, including nitrogen $(\mathrm{N})$, typically occur early in the season during canopy development and at the beginning of fruit production (Throop \& Hanson, 1997).

\section{Plant water relations and response of blueberry to drought}

\subsection{Fundamentals of plant water potential}

The growth, function, productivity, and water use of a plant are intimately related to its water status. Various parameters are used as indicators of plant water status, the most common of which is tissue or organ water potential. Values are typically expressed in units of pressure such as megapascals $(\mathrm{MPa})$, bars, or atmospheres or in units of height or hydraulic head. In plants, the principle components affecting water potential is solute concentrations in cell water and turgor pressure caused by rigidity of the cell wall. For practical purposes, the water potential of free water is considered zero. Therefore any movement of water from wet soil to the plant requires a negative potential. Water potential measured at any point in the soil, plant, and atmosphere, referred to as the soil-plantatmosphere continuum, is a measure of the tendency of water to move away from that point. Water tends to move from places where its potential is high (e.g., moist soil) to places where its potential is lower (e.g., ambient air with relative humidity less than 99\%). The difference between leaf water potential and soil water potential (the latter near zero for moist soils) is an estimate of the driving force for water movement from soil to the foliage. Water readily moves from foliage to the atmosphere (via stomatal openings on the leaf surface; see below) due to relatively higher vapor pressure deficits in the atmosphere.

Plant water potential is often measured using a pressure chamber, sometimes referred to as a "pressure bomb" or a "plant water status console". To make a measurement, a severed part of a plant such as a leaf or branch is placed in an enclosed chamber with its freshly cut end protruding through a rubber seal. The air pressure in the chamber is then gradually increased until it just causes the exudation of xylem sap at the cut end (generally viewed with a magnifying glass). At this point, the resulting pressure of the sap is zero, so xylem pressure equals negative air pressure. If xylem osmotic potential can be 
ignored (which is often the case as it's usually near zero in most plants), xylem pressure is equal to xylem water potential, which can be the same as the water potential of the other tissues in the chamber (if water equilibration has been achieved) (for details, see Scholander et al., 1964).

Marked daily changes in the water potentials occur in the soil-plant-atmosphere continuum (Fig. 3). In most plants, leaf stomata close at night and as a result, transpiration essentially ceases, allowing root and leaf water to equilibrate with the soil water. The equilibration process may take hours to occur but generally happens before dawn. When the soil is wet and near field capacity, e.g., shortly after a rain or irrigation event, water potentials in the soil, root, and leaf approach zero at night. The stomata then open at dawn and transpiration begins, resulting in a decline in leaf water potential. Root and soil water potentials also decline shortly thereafter. If there is no additional rain or irrigation, leaf, root, and soil water potential becomes more and more negative. As the soil dries, the difference between root and soil water potential must become larger each day in order to sustain water movement from soil to the roots. In contrast, the difference between leaf and root water potential remains constant until the plant is no longer able to sustain a water potential gradient sufficient to absorb enough water to maintain leaf turgor, e.g., when leaf water potential reaches $-1.5 \mathrm{MPa}$. The leaf thus wilts at this point but recovers at night. If drought persists, the leaf may wilt permanently and tissue damage will result.

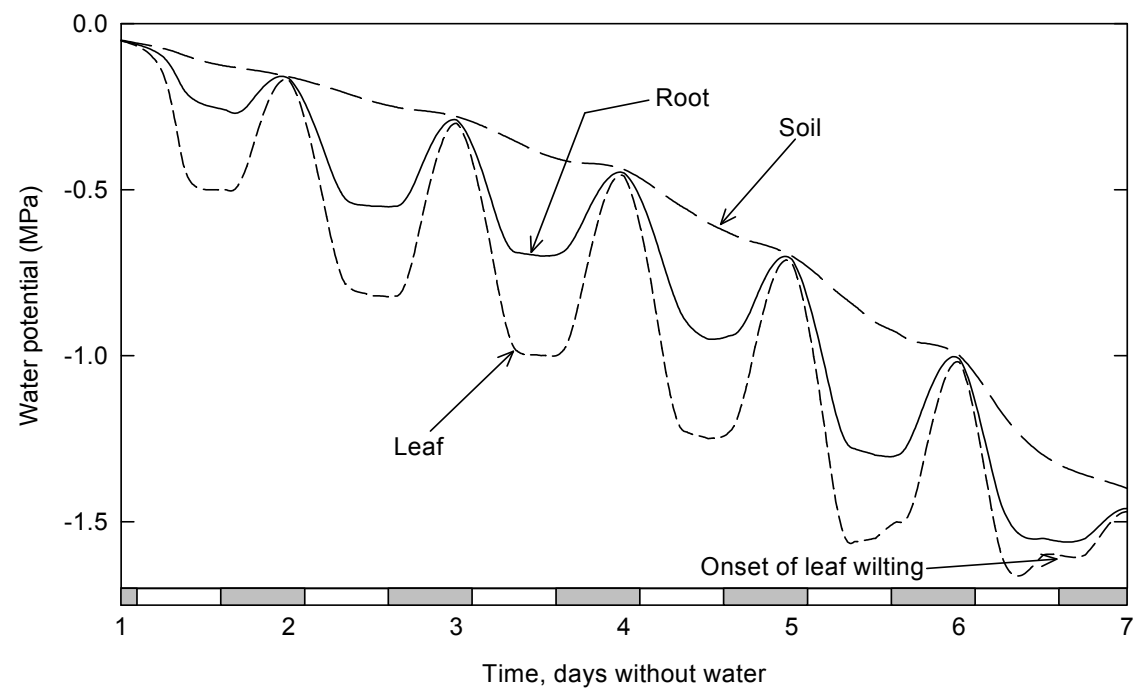

Fig. 3. Daily changes in soil, root, and leaf water potential following irrigation or a rain event. The shaded regions on the $x$-axis represent night and the white regions represent daytime. The figure is adapted from Slayter (1967). 

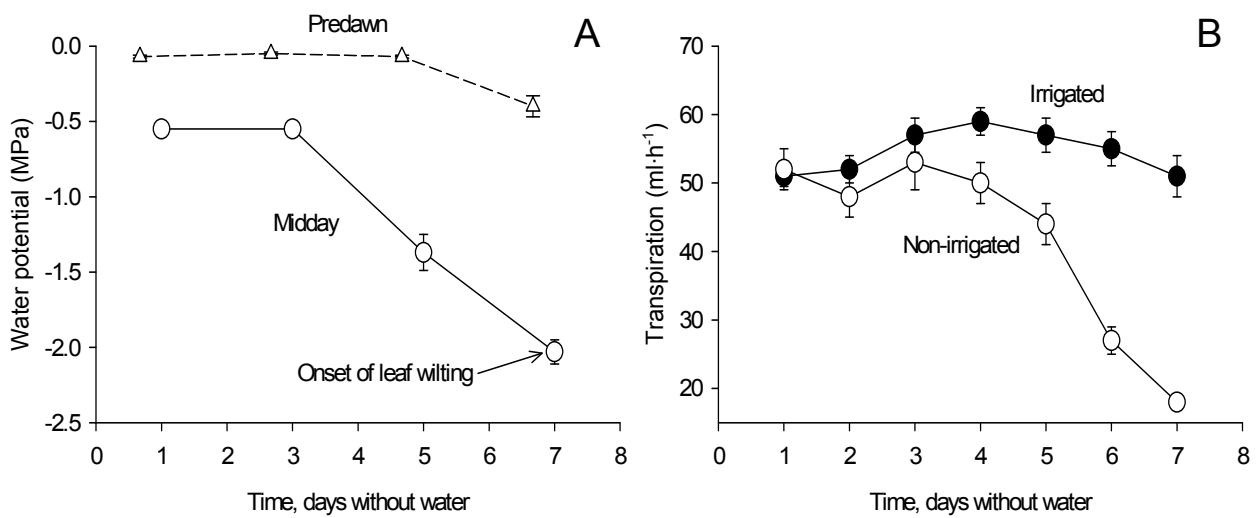

Fig. 4. A) Daily changes in predawn $(0500 \mathrm{~h})$ and midday $(1400 \mathrm{~h})$ leaf water potential and B) evapotranspiration of 3-year-old 'Elliott' blueberry plants grown in $23 \mathrm{~L}$ pots filled with sandy soil. Plants were either irrigated daily (B only) or exposed to drought for 7 days (A and B). Each symbol represents the mean of six plants and error bars represent one standard error.

\subsection{Relationship between plant water potential and evapotranspiration in blueberry}

An example of how water potential changes in a blueberry plant during the onset of drought is shown in Fig. 4. Although changes will differ somewhat among cultivars (Bryla and Strik, 2007), leaf water potential, measured either at predawn or at midday, declines as predicted when soil water is depleted over time. After 3 to 4 days without water, evapotranspiration also declines, demonstrating the proportional relationship between plant water potential and crop water use. This relationship is well illustrated by examining the response of stomatal conductance to changes in leaf water potential. Stomatal conductance is used to quantify gas diffusion processes, such as transpiration and $\mathrm{CO}_{2}$ assimilation, between plants and the atmosphere. The usual pathway for $\mathrm{CO}_{2}$ to enter a plant during photosynthesis is through controllable openings on the leaf surface known as stomata. Transpiration is an unavoidable consequence of water loss through these same openings. The openings are controlled by the presence of two guard cells surrounding a stomatal cavity inside the leaf. Stomatal conductance is most commonly measured using a diffusion porometer, which consists of a chamber for clamping onto the leaf surface and sensors to monitor changes in humidity inside the chamber (for details, see Pearcy et al., 1989). In most plants, including blueberry, stomata open during the day and close at night but will also close in response to water deficits during the day to help prevent excessive water loss during drought (Anderson et al., 1979). Under field conditions, stomatal conductance declined rapidly as leaf water potential approached values as high as -0.6 to $-0.8 \mathrm{MPa}$, indicating highbush blueberry is quite sensitive to even moderate levels of water stress (Fig. 5). Davies \& Johnson (1982) also determined that 'Bluegem' rabbiteye blueberry was sensitive to water potential changes but estimated that the critical water potential for total stomatal closure was at $-2.2 \mathrm{MPa}$. By comparison, critical water potentials as low as $-3.5 \mathrm{MPa}$ have been reported in apple (Davies \& Lasko, 1979). 


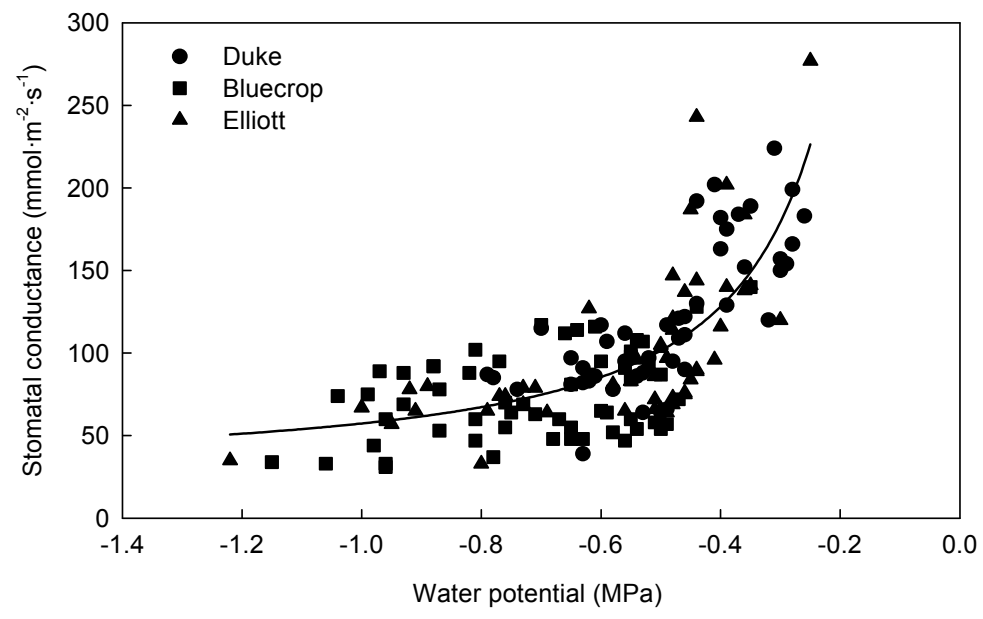

Fig. 5. Relationship between leaf stomatal conductance and midday (1400 h) leaf water potential in mature 'Duke', 'Bluecrop', and 'Elliott' blueberry plants grown under field conditions. Adapted from Bryla \& Strik (2006).

Under field conditions, water stress often develops in blueberry within 3 to 7 days without rain or irrigation during summer, varying depending on plant age, cultural practices, phenological development, soil texture, and weather conditions (Hess et al., 1997). Stress symptoms include reduced shoot growth, increased root growth, lower water use, and less photosynthesis. Young, succulent shoots and leaves wilt readily under dry conditions, and if drought persists, leaf margins and tips may become necrotic and scorched. This scorching is similar in appearance to salt injury often associated with over-fertilization (Caruso \& Ramsdell, 1995). Internode length is shortened by water deficits, as is the duration of shoot growth when these deficits occur early in the growing season (B. Strik, personal communication). Susceptibility to water deficits may increase after the initiation of fruit ripening. Berries of small fruit crops, including blueberry, however, have few stomata. The majority of the water lost by the plant occurs through the leaf surfaces with fruit playing a minor direct role in plant water losses. Resistance to water deficits may be enhanced by osmotic adjustment (e.g., Zhang \& Archbold, 1993) or by increased root to shoot ratios (e.g., Renquist et al., 1982), leaf thickness and waxiness (Anderson et al., 1979), and cell wall elasticity (e.g., Savé et al., 1993).

In France, mature 'Bluecrop' blueberries exposed to drought closed their stomates and reduced transpiration gradually within 9 days after withholding irrigation (Améglio et al., 2000). Upon rewatering, recovery was slow,with stomatal conductance and transpiration returning to normal after 7 to 9 days. A vulnerability curve presented in the same study indicated that embolism in the xylem vessels was negligible when leaf water potential was -1.2 $\mathrm{MPa}$ or higher but increased rapidly at lower water potentials. To develop the curve, hydraulic conductance was measured at different applied pressures on 2 to $3 \mathrm{~cm}$-long stem segments excised under water (Sperry et al., 1988). Percent loss of hydraulic conductance was $50 \%$ at -1.4 $\mathrm{MPa}$ and $100 \%$ at $-2.1 \mathrm{MPa}$. However, in situ embolism measured during actual water stress 
was usually less than $30 \%$. Apparently, rapid reduction in stomatal conductance reduced water loss and maintained water potential at the threshold of cavitation in 'Bluecrop', protecting it from total xylem cavitation and enhancing its ability to recover from drought.

Bryla \& Strik (2007) examined the onset of water stress in three cultivars of 5-year-old highbush blueberry plants in Oregon, USA, including 'Duke', an early-season cultivar that ripens in late June to mid July, 'Bluecrop', a mid-season cultivar that ripens in mid July to early August, and 'Elliott', a late-season cultivar that ripens in early August to early September. Plants were exposed to water stress during each ripening period. During each period, stem water potential dropped only slightly within the first 3 to 4 days after irrigation was withheld but declined substantially, in many cases, after 5 to 7 days without irrigation (Fig. 6A-C). This later decline was associated with reduced rates of root water uptake, indicated by smaller changes in soil water content in each treatment. Within each cultivar, the most apparent decline in water potential occurred when fruit were in their final stages of ripening, just prior to harvest. The differences in water potential were attributed to seasonal variation in water use among the cultivars (Fig. 6D-F). 'Duke' acquired the most water, using 5 to $10 \mathrm{~mm}$ per day from mid-May to mid-August, while 'Elliott' acquired the least, using only 3 to $5 \mathrm{~mm}$ per day. Water use by 'Bluecrop' was intermediate. Water use was highest during fruit filling and ripening but declined markedly after harvest, especially in 'Duke', which ripened earliest. A sharp decline in water use was less apparent in 'Elliott', which had the latest and most extended fruit ripening period. Mingeau et al. (2001) reported that almost $55 \%$ of the total seasonal water requirements of 'Bluecrop' occurred in June and July during fruit ripening; once fruit were picked, plant water requirements decreased to nearly half. Higher rates of stomatal conductance and water use have been associated with increased photosynthetic activity during fruit ripening in lowbush blueberry (Hicklenton et al., 2000). Thus, as ripening periods differ among cultivars, water requirements at any given time of the year will also differ.
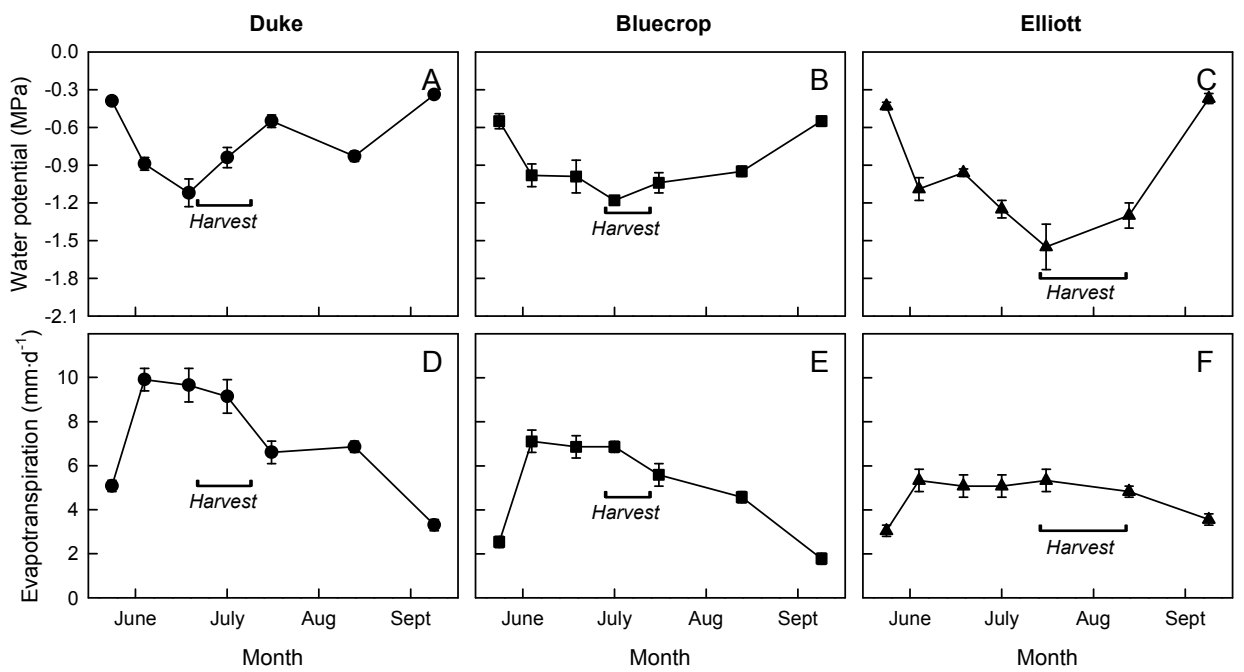

Fig. 6. Seasonal changes in (A-C) leaf water potential and (D-F) evapotranspiration in mature (A, D) ‘Duke', (B, E) ‘Bluecrop', and (C, F) 'Elliott' blueberry plants. Adapted from Bryla \& Strik (2007). 


\section{Estimating evapotranspiration for irrigation scheduling in blueberry}

Irrigation scheduling, a key element of proper water management, is the accurate forecasting of water application (amount and timing) for optimal crop production (yield and fruit quality). The goal is to apply the correct amount of water at the right time to minimize irrigation costs and maximize crop production and economic return. Many techniques and technologies can forecast the date and amount of irrigation water to apply. The appropriate technique or technology is a function of the irrigation water supply, technical abilities of the irrigator, irrigation system, crop value, crop response to irrigation, cost of implementing technology, and personal preference. This section illustrates tools and techniques available for improving irrigation scheduling in blueberry.

\subsection{Procedures for calculating blueberry evapotranspiration}

Irrigation is required of course whenever precipitation is inadequate to meet the water demands of the crop, which, depending on latitude and weather patterns, can occur anytime from March through October in the northern hemisphere and from September to May the in southern hemisphere. In Oregon, USA, average seasonal water requirements for blueberry range from 15 to $49 \mathrm{~mm}$ per week (Hess et al., 2000). The highest irrigation requirements typically occur in July, although actual peak irrigation demands vary considerably throughout the summer depending on weather, location, and stage of fruit development. Nearly all water taken up by a crop is lost by transpiration, a process that consists of the vaporization of liquid water contained in the plant to the atmosphere; only a tiny fraction is used within the plant. The water, together with some nutrients, is absorbed by the roots and transported through the plant. The water is vaporized within the leaves and transferred to the atmosphere through the leaf stomata. Water use by the crop is fairly complicated to estimate and will depend on numerous factors, including weather, plant age and cultivar, soil conditions, and cultural practices. Water is also lost from the soil surface by evaporation, particularly within the first few days after rain or irrigation. Crop transpiration and soil evaporation occur simultaneously and there is no easy way of distinguishing between the two processes. Therefore, crop water requirements are typically estimated as the combination of the two processes, collectively termed crop evapotranspiration (ET).

Weekly estimates of crop ET are often accessible on the internet from weather-based websites, e.g., AgriMet (Pacific Northwest Cooperative Agricultural Weather Network; http://www.usbr.gov/pn/agrimet/) and CIMIS (California Irrigation Management Information System; http://wwwcimis.water.ca.gov/cimis/welcome.jsp). These sites obtain data from a satellite-based network of automated agricultural weather stations located throughout a region of interest. Weather data are used to estimate ET of a reference surface such as grass $\left(\mathrm{ET}_{\mathrm{o}}\right)$ or alfalfa $\left(\mathrm{ET}_{\mathrm{r}}\right)$, which is then converted to crop ET using an appropriate crop coefficient $\left(K_{c}\right)$ for blueberry (for details, see Allen et al., 1998). A crop coefficient represents the relative amount water used by a crop (e.g., blueberry) to that used by grass or alfalfa. Therefore, the value will change over the season as the crop canopy develops. Crop coefficients will also differ depending on whether crop ET is calculated using $\mathrm{ET}_{\mathrm{o}}$ or $_{\mathrm{ET}}$. An example of crop coefficients used for calculating blueberry ET based on weather-based estimates of $\mathrm{ET}_{\mathrm{r}}$ is shown in Fig. 7A. The coefficients increase as the canopy develops from bud break to the beginning of fruit ripening and then gradually declines until leaf senescence and dormancy. Blueberry reaches full effective canopy cover when the first blue fruit appear and it is at this stage that water use by blueberry is equal to alfalfa and $K_{c}=1$. 

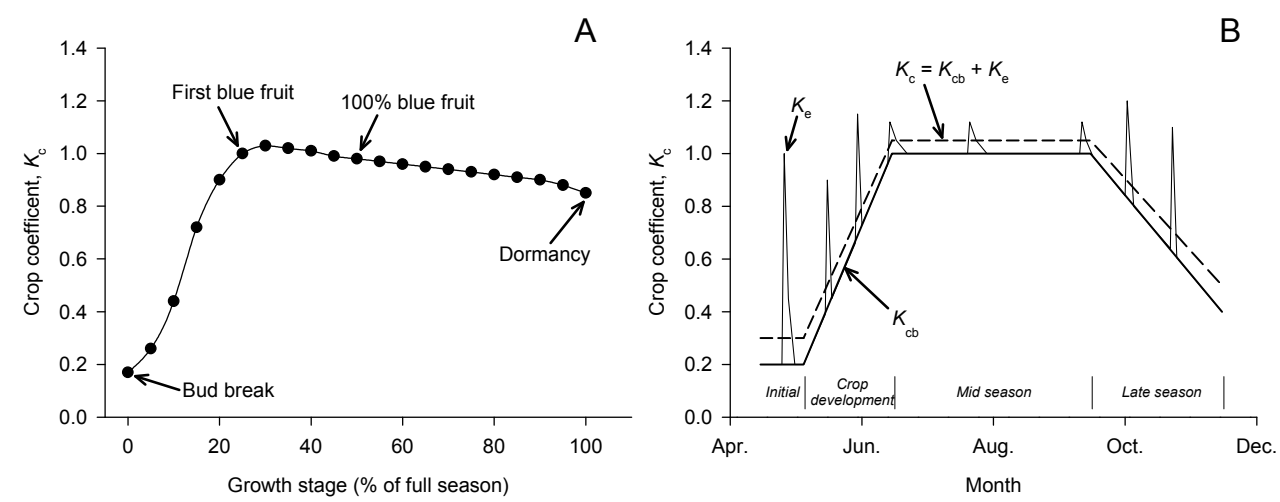

Fig. 7. Crop coefficient curves for highbush blueberry from (A) AgriMet and (B) FAO-56. Blueberry ET is calculated at various stages of crop development by multiplying $K_{\mathrm{c}}$ by $\mathrm{ET}_{\mathrm{r}}$ or $\mathrm{ET}_{\mathrm{o}}$, respectively.

The FAO-56 guidelines for calculating crop ET recommends using a simplified segmented $K_{c}$ curve approach whereby the growing season is divided into four distinct stages: initial, crop development, mid season, and late season (Allen et al., 1998; Fig. 7B). In perennial crops, the initial stage begins at bud break or the green-up date when new leaves are initiated and continues to about $10 \%$ ground cover. The $K_{\mathrm{c}}$ during the initial stage $\left(K_{\mathrm{c}}\right.$ ini) is predominated by soil evaporation and therefore is large when the soil is wet from rain or irrigation and small when the soil is dry. The crop development stage runs from $10 \%$ ground cover to effective full cover. Again, full cover in blueberry occurs about when the fruit just begin to turn blue but may be prior to fruit ripening in later season cultivars. The mid-season stage runs from full cover to the beginning of leaf yellowing, i.e., the start of senescence. It is the longest stage during the growing season and is the period in which $K_{\mathrm{c}}$ reaches its maximum value $\left(K_{\mathrm{c}} \mathrm{mid}\right)$. The late-season stage runs from leaf yellowing to complete leaf senescence $\left(K_{\mathrm{c}}\right.$ end). The $K_{\mathrm{c}}$ values increase linearly from $K_{\mathrm{c}}$ ini to $K_{\mathrm{c}}$ mid and decrease from $K_{\mathrm{c} \text { mid }}$ to $K_{\mathrm{c}}$ end; however, the slopes will vary depending on the length of each stage. Crop transpiration and soil evaporation may be combined into a single coefficient, $K_{\mathrm{c}}$, (single crop coefficient approach) or separated into two coefficients: a basal crop coefficient $\left(K_{\mathrm{cb}}\right)$, which represents primarily the transpiration component of ET, and a soil evaporation component $\left(K_{\mathrm{e}}\right)$ (dual crop coefficient approach). In this later case, $K_{\mathrm{c}}$ is replaced by $K_{\mathrm{cb}}+K_{\mathrm{e}}$. The $K_{\mathrm{c}}$ values listed for berries (bushes) in FAO-56 are $0.30\left(K_{\mathrm{c} \mathrm{ini}}\right), 1.05\left(K_{\mathrm{c} \mathrm{mid}}\right)$, and $0.50\left(K_{\mathrm{c}}\right.$ end); the $K_{\mathrm{cb}}$ values are $0.20\left(K_{\mathrm{cb} \text { ini }}\right), 1.00\left(K_{\mathrm{cb} \text { mid }}\right)$, and $0.40\left(K_{\mathrm{cb} \text { end }}\right)$. Blueberry ET in this case is calculated at each stage of development by multiplying $K_{\mathrm{c}}$ or $K_{\mathrm{cb}}+K_{\mathrm{e}}$ by $\mathrm{ET}_{\mathrm{o}}$. See Allen et al. (1998) for procedures on calculating $K_{\mathrm{e}}$.

To adjust for smaller plant size in new plantings, Fereres et al. (1982) developed a correction factor, $F_{\mathrm{c}}$, by correlating crop ET to canopy development using data from young almond trees. The relationship was modified by Holzapfel et al. (2004) to estimate ET for young blueberries using the following equation:

$$
\mathrm{ET}_{\text {blueberry }}=K_{\mathrm{c}} \mathrm{ET}_{\mathrm{o}} F_{\mathrm{c}}
$$

where 


$$
F_{\mathrm{c}}=K_{1} S_{\mathrm{h}}+K_{2}
$$

and

$$
S_{\mathrm{h}}=\frac{A_{\mathrm{s}}}{H L}
$$

$S_{\mathrm{h}}$ is percent shade (10 $\left.\leq S_{\mathrm{h}} \leq 70\right), K_{1}$ and $K_{2}$ are constants of the shadow factor adjusted for irrigation method (equal to 0.0118 and 0.25 , respectively, for drip and 0.0127 and 0.1125 , respectively, for microsprays), $A_{\mathrm{s}}$ is the area of the soil surface shaded by the crop canopy at $1200 \mathrm{~h}\left(\mathrm{~m}^{2}\right), H$ is the distance between rows $(\mathrm{m})$, and $L$ is the distance between plants within the row $(\mathrm{m})$. The correction factor, $F_{c}$, is a function of cultural practices, the type of irrigation system used, planting density, and climatic conditions of the area. Once a planting has $70 \%$ cover or larger, it reaches an adult condition where crop ET is no longer a function of plant size (Bryla \& Strik, 2007). However, because blueberry is a relatively short crop $(<2.0 \mathrm{~m}$ tall and $<1.5 \mathrm{~m}$ wide) with a fairly wide rows (3.0-3.6 $\mathrm{m}$ apart), $F_{\mathrm{c}}$ can also be used to adjust for lack of canopy cover between rows in mature plantings.

Normally, irrigation should be scheduled to replace any water lost by crop ET. Keep in mind, however, that these are ET estimates for mature, healthy, well-irrigated blueberry plants. Adjustments to these values are needed when plants are young or stressed (e.g., nutrient deficient). Under these circumstances, irrigators should reduce the amount of irrigation water applied but pay close attention to soil moisture conditions to avoid underor over-irrigating their crop. There are numerous devices available for monitoring soil moisture, although some are more accurate and reliable than others. Many of these monitoring devices need to be calibrated to a particular site so that gathered data can be related to actual soil moisture conditions. Soil moisture monitors should be installed within the root zone (usually $0.15-0.30 \mathrm{~m}$ deep) of a representative plant and should not be located directly beneath an irrigation emitter.

\subsection{Adjusting water applications for irrigation system efficiency}

It is important to understand that a crop's irrigation requirements differ considerably from its water requirements. Crop water requirements indicate the total amount of water directly used by a crop but do not account for any extra water needed to compensate for non-beneficial water use or loss, e.g., run-off, deep percolation, evaporation, wind drift, ground cover, weeds, etc. Additionally, irrigation systems do not apply water with $100 \%$ uniformity (Burt et al., 2000). For accurate irrigation scheduling, these losses must be evaluated for each system. The most common systems used to irrigate blueberry are sprinklers and drip.

Average irrigation application efficiencies for well-maintained solid set sprinkler systems generally range from $65-75 \%$, which largely depends on the quality of sprinkler overlap. Close spacing and newer sprinkler heads help improve sprinkler water application efficiency. Brand new drip systems, on the other hand, can generally be designed with 85$93 \%$ efficiency, except in cases with major elevation changes. Beware that neglected drip systems have been shown to have actual efficiencies closer to $60-80 \%$. Primary causes for low efficiencies include flow variation due to poor system design, emitter plugging, and pressure differences within the field. 
In northwest Oregon, USA, average irrigation requirements throughout the growing season are estimated to range from 4-16 mm of water per day with sprinklers and 1-4 mm of water per day by drip (Table 1). The highest irrigation requirements typically occur in July, although actual peak irrigation demands will vary throughout the summer depending on

\section{Average daily water requirements}

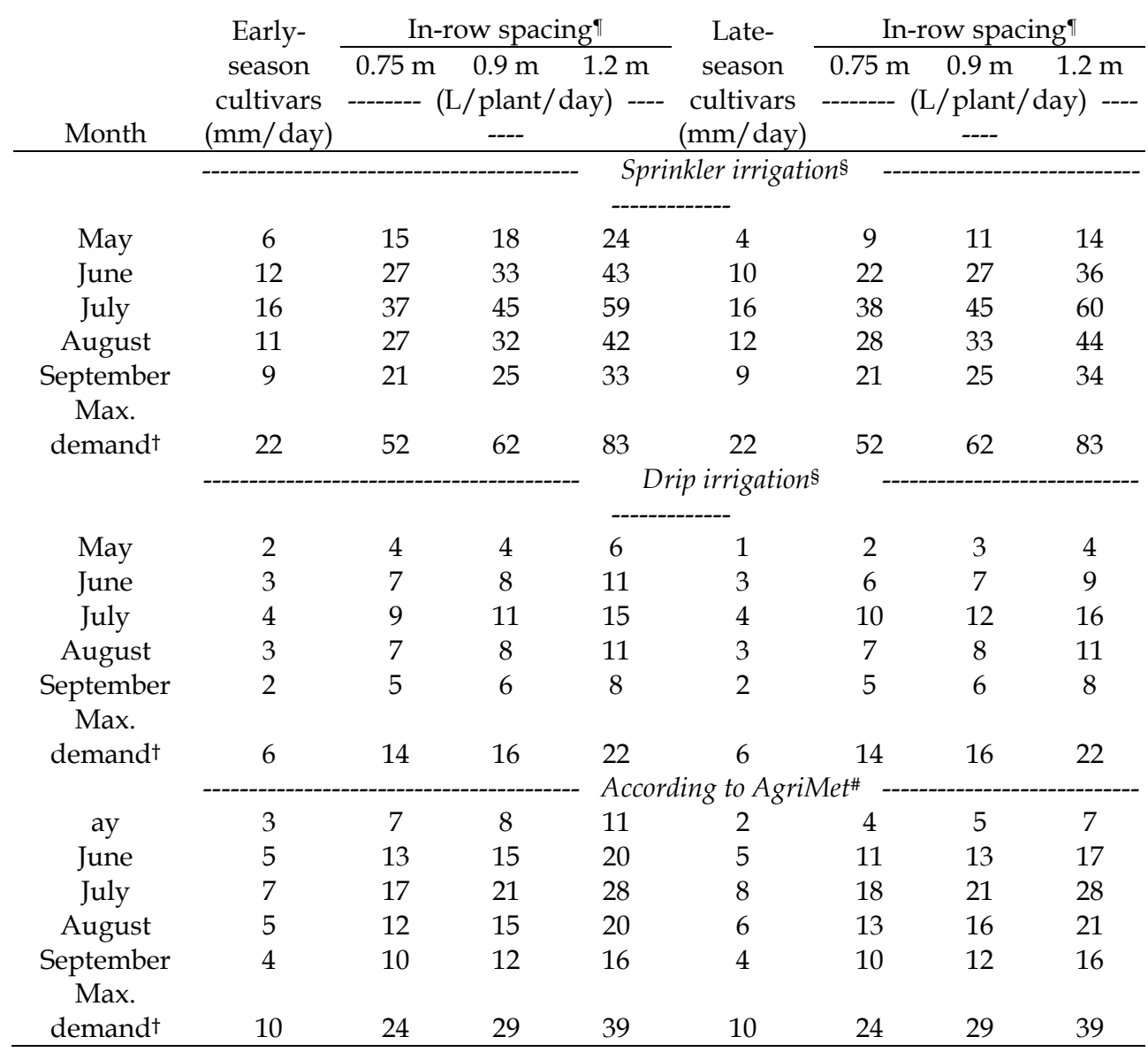

Calculations are based on a 3.0-m wide between-row spacing.

$\S$ Values should be adjusted for precipitation before scheduling irrigation.

\#Obtained from AgriMet website (http://www.usbr.gov/pn/agrimet/). These values must be adjusted for water application efficiency of the irrigation system in order to estimate irrigation water requirements.

†Occurs when conditions are hot $\left(>35^{\circ} \mathrm{C}\right)$, dry, and windy in mid-July to early-August.

Table 1. Average daily water requirements for healthy, mature highbush blueberry plants in northwest Oregon. Note that values will differ at other locations, depending on latitude, elevation, and local weather conditions. 
weather and stage of fruit development. A well-maintained drip system generally requires only about $25 \%$ of the water needed with sprinklers due to the higher efficiency associated with drip irrigation. It should be noted, however, that the actual crop water use by sprinkler and drip-irrigated blueberries is theoretically identical. Irrigation requirements will also vary of course with location but are easily adjusted when calculating crop ET.

\subsection{Timing of water applications}

The timing or frequency of water applications will depend on soil texture (e.g., sand versus clay), the irrigation system used (e.g., drip versus sprinkler), the rate at which the plant is using water, and the overall development of the plant's root system. Blueberry is a shallowrooted plant compared to many perennial fruit crops. The roots of highbush blueberry are usually located in the top $0.5 \mathrm{~m}$ of soil and are often most concentrated near the soil surface (Fig. 8). Patten et al. (1988) found that $90 \%$ of the roots in rabbiteye blueberry, which tends to produce deeper roots than highbush cultivars, were less than $0.45 \mathrm{~m}$ deep even when plants were not mulched (drier soil surface) and were irrigated by drip (concentrated soil wetting pattern). Consequently, when water demands are high, blueberry plants quickly depletes the water from their root zone and require frequent applications of water in order to avoid water stress.

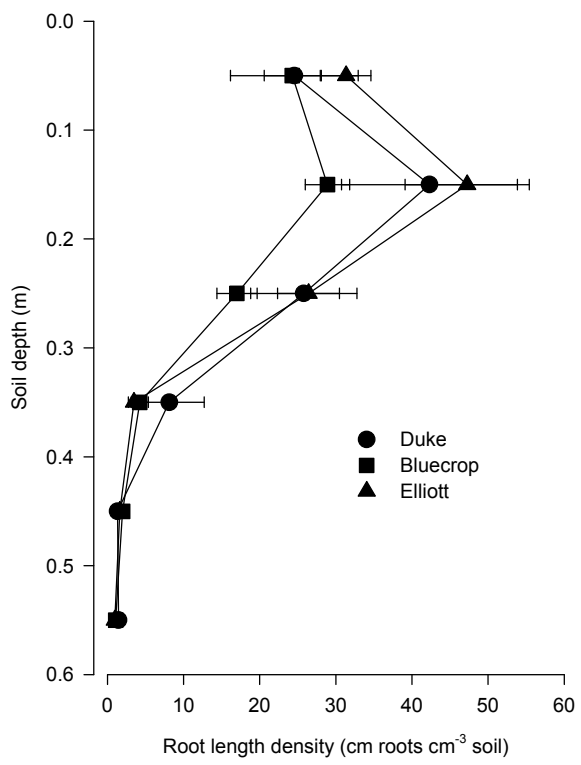

Fig. 8. Root length density of mature 'Duke', 'Bluecrop', and 'Elliott' blueberry plants. Roots were collected at 0.1-m depth increments. Adapted from Bryla \& Strik (2007).

Frequent water applications are especially important when using drip, which tends to restrict soil wetting and thus produces a smaller root system. When done properly, frequent irrigations are beneficial and often increase growth and yield in many horticultural crops. For example, frequent irrigation by drip in peach increased fruit size and yield compared to other irrigation methods by maintaining higher tree water status between irrigations (Bryla et al., 2005). It may also be important to apply water to both sides of the plant. Abbott \& Gough 
(1986) found that when water was applied to only one side of the blueberry bush, growth and production was severely restricted on the other side. Irrigators, however, particularly those using drip, should be careful to avoid the temptation to over-irrigate. Over-irrigation depletes the root zone of much-needed oxygen, thus reducing both root growth and nutrient uptake and leading to a host of potential root disease problems. Davies \& Flore (1986) observed, in both highbush and rabbiteye blueberry, that stomatal conductance declined within 5 days and photosynthesis declined within 9 days when plants were grown in flooded soil, and 18 days or more were required for each process to recover to pre-flood conditions.

High-frequency irrigation may be especially beneficial and perhaps even required when organic matter is incorporated into the planting bed. Organic matter often reduces water holding capacity of the soil and can lead to problems with hydrophobicity. Soil hydrophobicity is the lack of affinity of soil to water and is thought to be caused primarily by a coating of long-chained hydrophobic organic molecules, such as those released from decaying organic matter, on individual soil particles (DeBano, 2000). Hydrophobic soils often become very difficult to rewet once they dry out. White (2006) found that even with drip irrigation, sawdust incorporated into raised planting beds made it difficult to retain adequate moisture in the upper portions of the soil where many of the blueberry roots were located. To compensate, much longer and more frequent irrigation was required in beds with incorporated sawdust than without. Personal observations indicate that, even after 50 $\mathrm{mm}$ of rainfall, dry beds with incorporated sawdust tend to remain dry and do not become fully saturated until the following season. Krewer et al. (2002) found that water infiltrated much more readily through sandy soil amended with pine post and pole peelings (2-45 $\mathrm{mm}$ long pieces of bark and wood) than soil amended with milled pine bark, although plant growth was slightly less in the soil with the larger-sized product.

\subsection{Other tools and techniques}

Other potential methods available to schedule irrigation in perennial crops include soil-based and plant-based monitoring approaches. The soil-based approach relies on soil moisture monitoring devices set in a feedback mode to automatically open and close irrigation valves when soil moisture reaches a certain level of dryness. Unfortunately, these systems are not universal and require careful calibration from site to site to operate properly. Little research has been done with these soil-based systems on blueberry. The plant-based approach may be the most accurate method to schedule irrigations and avoid water stress during critical stages of growth but is probably also the most complex and labor intensive. This type of approach uses measures of plant growth or water status to determine exactly when irrigation is needed. Leaf water potential measurements are currently used as a successful tool for scheduling irrigation in fruit trees. Interpretation of water potentials for irrigation scheduling is complicated however by the fact that values are influenced by weather conditions. For example, leaf water potential tends to decrease with time over the season regardless of adequacy of irrigation due to increasing evaporative demand. To overcome this problem, a fully irrigated baseline (reference) value of stem water potentials must be calculated for any given value of midday air vapor pressure deficit (VPD). A baseline value is applicable to a wide variety of soil and irrigation conditions and has provided stem water potential guidelines for fully irrigated fruit trees grown in California using relative humidity and air temperature (Shackel et al., 1997). Once developed, data collected from weather stations can be used for baseline estimates in commercial fields throughout a region. Irrigation scheduling is accomplished by comparing actual water potentials to reference values; when actual values 
fall below reference values, irrigation is increased. Typically, irrigation is increased by $5-10 \%$ above the previous week's rate when mean weekly stem water potentials are lower than reference values, and decreased by $5-10 \%$ when actual and reference values are equal for two consecutive weeks. To ensure plants are not over or under irrigated, soil water content should also be monitored at least monthly. Soil water content measurements may also provide information to help determine initial irrigation rates based on root-zone changes in the soil water profile during the first few weeks of the growing season.

\section{Irrigation systems and considerations for water application}

Most commercial blueberry fields in the U.S. are irrigated by overhead sprinklers or drip (Strik \& Yarborough, 2005). Water is typically applied one to two times per week as needed with sprinklers and every one to three days with drip. Sprinkler systems are relatively simple to install and maintain, and when designed properly, obtain reasonable uniformity of water application. Some major advantages of sprinklers are that they can be used to maintain a cover crop, protect the crop from frost damage during subfreezing temperatures, cool the crop during hot conditions, and wash dust off the crop before harvest. Drip systems are somewhat more expensive to install and more difficult to maintain than sprinklers but offer superior water control and distribution uniformity, lower energy costs, improved application of fertilizer and other chemicals, improved cultural practices, including the ability to irrigate during harvest, fewer weed and disease problems, and reduced food safety risks when using surface water to irrigate (Kruse et al., 1990). A few growers are also using microsprays on blueberry. Microspray irrigation offers advantages similar to drip but applies the water to the soil surface by a small spray. Although not commonly used in blueberry, Holzapfel et al. (2004) found in Chile that production was higher with microsprays than with drip. Because microsprays wet more soil volume than drip, plants tend to produce a larger root system, which may be a considerable advantage in a shallow, densely-rooted crop like blueberry (Patten et al., 1988).

\subsection{A comparison of irrigation methods}

Bryla et al. (2011) compared the water requirements for growing blueberry with sprinklers, drip, and microsprays to determine which method produces the most growth after planting. Two cultivars, 'Duke' and 'Elliott', were evaluated. By the end of the second growing season, drip irrigation produced the largest 'Elliott' plants among the irrigation methods with $42 \%$ less water than microsprays and $56 \%$ less water than sprinklers. The benefit of drip in 'Elliott' was likely a result of superior plant water status due to higher soil water content in the vicinity of the roots. Drip also maintained higher plant water potentials than microsprays in other perennial fruit crops, including peach and almond (Bryla et al., 2005; Edstrom \& Schwankl, 2004). Drip irrigation, however, was not beneficial in 'Duke' (Bryla \& Linderman, 2007). In this case, plants irrigated by drip were only half the size of those irrigated by sprinklers or microsprays. Root sampling revealed that 'Duke' was infected by Phytophthora cinnamomi, the causal organism often associated with root rot in blueberry, and the wetter soil conditions with drip were more favorable to the disease. Therefore, in terms of early plant growth and water use efficiency, drip irrigation was the best method out of the three to establish healthy blueberry plants. However, sprinklers and microsprays may be better alternatives for cultivars such as 'Duke' that are highly susceptible to root rot, especially at sites with heavy soils or a history of the disease. 
Fruit were first harvested beginning the third year after planting in 'Elliott' and fourth year after planting in 'Duke' (Fig. 9). During the first 4 years of production, yields were similar in 'Duke' whether plants were irrigated by sprinklers or microsprays but lower when irrigated by drip due again to higher incidence of root rot. Root rot does not usually result in plant death in blueberry, although it will reduce growth and production even when plants are treated with fungicide, as we did each year beginning the third year after planting. In 'Elliott', yields were slightly higher with drip than with sprinklers and microsprays during the first year of production and still higher than sprinklers the second year. However, by the third year, yield was similar between drip and sprinklers but higher when plants were irrigated by microsprays. This latter result agrees with that of Holzapfel et al. (2004), who compared drip and microsprays in 'Bluecrop'. They positioned the microsprays under the canopy on each side of the plants whereas we hung the microsprays above the canopy between every other plant. Hanging the microsprays reduced the number of microsprays needed and reduced problems with plants interfering with the microsprays.
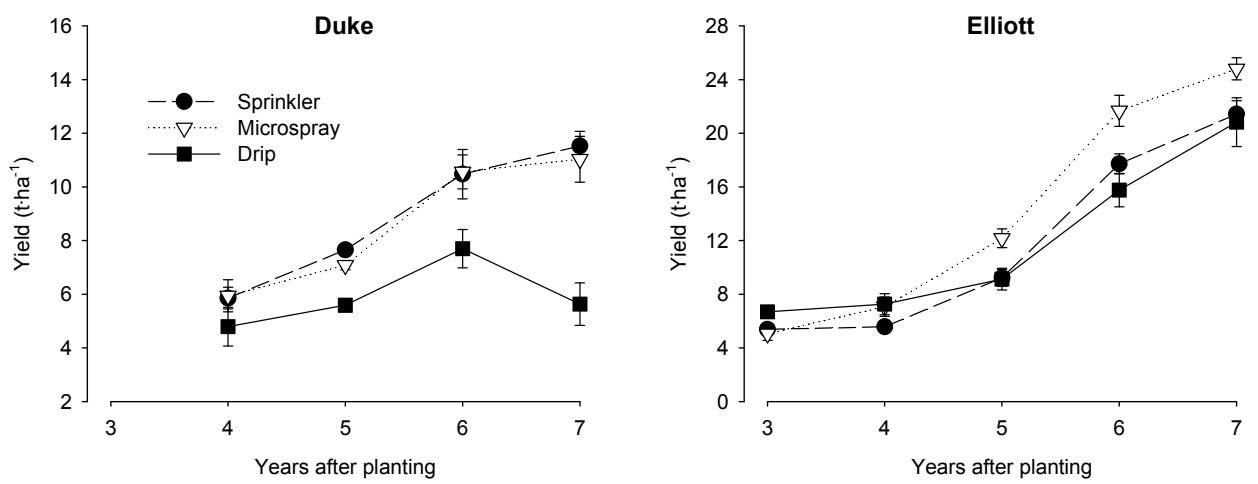

Fig. 9. Marketable fruit yield of 'Duke' and 'Elliott' blueberry irrigated by sprinklers, microsprays, or drip. Each symbol represents the mean of five plots with six plants each, and error bars represent one standard error.

\subsection{Drip lateral placement}

Most new plantings of blueberry are irrigated by drip. One or two laterals of drip tubing is used per row, and the tubing is usually either laid on the ground or hung on a trellis wire with one or two laterals of tubing used per row. Drip emitters are often spaced 0.3-0.6 m apart and range from 1-4 LPH, depending on the design of the system. The goal is to distribute water evenly around the plants; thus the optimum number and placement of emitters will vary depending on plant size, soil type, cultural practices, and weather conditions. Proper lateral placement improves growth and production and increases water use efficiency. It may also reduce problems with soil pathogens (Café-Filho \& Duniway, 1996).

We examined the potential of using different drip configurations to reduce the incidence of root rot in 'Duke'. The configurations included two laterals of drip tubing placed on the soil surface on each side of the plants, two laterals buried $0.15 \mathrm{~m}$ deep on each side of the plants (approximately $0.3 \mathrm{~m}$ from the crown), and one lateral suspended $1.2 \mathrm{~m}$ above the plants. 
After 2 years, plants irrigated by buried drip were larger and healthier than those irrigated by surface drip, particularly when the laterals were placed near the base of the plants. Signs of water stress, including marginal leaf necrosis, were evident in plants irrigated by surface drip, even after 3 years. In comparison, there was no evidence of water stress in plants irrigated by subsurface drip. The use of subsurface drip maintained lower soil water content near the plants, which reduced root rot and encouraged more lateral root development. Subsurface drip also eliminated water runoff and soil erosion observed with both the surface drip configurations.

\section{Conclusions and future research needs}

Blueberry is a shallow-rooted crop highly susceptible to water deficits. Within 3 to 4 days without irrigation, both plant water potential and transpiration steadily decline. The plants appear to be most affected by soil water limitation in the later stages of berry development, particularly during fruit ripening, as well as after harvest during fruit bud set. During fruiting, early-season cultivars with a compressed fruiting period have higher water requirements than later-season cultivars and therefore may be more readily exposed to water stress without rain or irrigation. Crop coefficients are available to estimate crop water requirements for irrigation scheduling in blueberry; however, the accuracy of these coefficients requires further testing using various cultivars and cultural practices (e.g., flat versus raised beds, different mulch materials, etc.).

The most common methods used to irrigate blueberry are sprinklers and drip. The amount of water applied by sprinklers or drip must be adjusted for application efficiency when irrigation is scheduled based on estimated water requirements. In general, estimated water requirements are less than the irrigation requirements when blueberry is irrigated by sprinklers but are higher than when irrigated by drip. The higher requirements with sprinklers are due to the relatively low application efficiency (approximately $50 \%$ water is applied between rows where there are no roots) while the lower requirements with drip are due to high application efficiency (water is applied directly to the roots) and the fact that canopy cover generally averages less than $50 \%$ even as plants approach full maturity, which thereby reduces the actual crop ET.

Drip irrigation improves growth and early production compared to sprinklers, provided the blueberry plants are healthy. Drip, however, may also increase incidence of root rot in susceptible cultivars and is not recommended at sites with heavy soils or a history of the disease. In healthy plants, yield differs little whether plants are irrigated by sprinklers or drip but may be higher when plants are irrigated by microsprays. Microsprays are not traditionally used in blueberry, but the method shows considerable promise and requires further study to determine its potential in commercial blueberry production systems. Work is still needed on the impacts of irrigation methods and scheduling strategies on fruit quality in blueberry, including such irrigation practices as cooling the fruit during hot weather.

\section{References}

Abbott, J.D. \& Gough, R.E. (1986) Split-root water application to highbush blueberry plants. HortScience, Vol. 21, pp. 997-998, ISSN 0018-5345 
Abbott, J.D. \& Gough, R.E. (1987) Seasonal development of highbush blueberry roots under sawdust mulch. Journal of the American Society for Horticultural Science, Vol.112, pp. 60-62, ISSN 0003-1062

Allen, R.G., Pereira, L.S., Raes, D. \& Smith, M. (1998) Crop Evapotranspiration. Guidelines for Computing Crop Water Requirements, Food and Agriculture Organization of the United Nations Irrigation and Drainage Paper 56, ISBN 92-5-104219-5, Rome, Italy

Améglio, T., Le Roux, X., Mingeau, M. \& Perrier, C. (2000) Water relations of highbush blueberry under drought conditions. Acta Horticulturae, Vol.537, pp. 273-278, ISSN 0567-7572

Anderson, P.C., Buchanan, D.W. \& Albrigo, L.G. (1979) Water relations and yields of three rabbiteye blueberry cultivars with and without drip irrigation. Journal of the American Society for Horticultural Science, Vol.104, pp. 731-736, ISSN 0003-1062

Bryla, D.R. \& Linderman, R.G. (2007) Implications of irrigation method and amount of water application on Phytophthora and Pythium infection and severity of root rot in highbush blueberry. HortScience, Vol.42, pp. 1463-1467, ISSN0018-5345

Bryla, D.R. \& Strik, B.C. (2006) Variation in plant and soil water relations among irrigated blueberry cultivars planted at two distinct in-row spacings. Acta Horticulturae Vol. 715, pp. 295-300, ISSN 0567-7572

Bryla, D.R. \& Strik, B.C. (2007) Effects of cultivar and plant spacing on the seasonal water requirements of highbush blueberry. Journal of the American Society for Horticultural Science, Vol.132, pp. 270-277, ISSN 0003-1062

Bryla, D.R, Gartung, J.L. \& Strik, B.C. (2011) Evaluation of irrigation methods for highbush blueberry-I. Growth and water requirements of young plants. HortScience, Vol.46, pp. 95-101, ISSN 0018-5345

Bryla, D.R., Dickson, E., Shenk, R., Johnson, R.S., Crisosto, C.H. \& Trout, T.J. (2005) Influence of irrigation method and scheduling on patterns of soil and tree water status and its relation to yield and fruit quality in peach. HortScience, Vol.40, pp. 2118-2124, ISSN 0018-5345

Café-Filho, A.C. \& Duniway, J.M. (1996) Effects of location of drip irrigation emitters and position of Phytophthora capsici infections in roots on Phytophthora root rot of pepper. Phytopathology 86:1364-1369

Caruso, F.L. \& Ramsdell, D.C. (1995) Compendium of Blueberry and Cranberry Diseases. American Phytopathological Society Press, ISBN 978-0-89054-173-9, St. Paul., Minnesota, USA

Davies, F.S. \& Flore, J.A. (1986) Gas exchange and flooding stress of highbush and rabbiteye blueberries. Journal of the American Society for Horticultural Science, Vol.111, pp. 565571, ISSN 0003-1062

Davies, F.S. \& Johnson, C.R. (1982) Water stress, growth, and critical water potentials of rabbiteye blueberry (Vaccinium ashei Reade). Journal of the American Society for Horticultural Science, Vol.107, pp. 6-8, ISSN 0003-1062

Davies, F.S. \& Lakso, A.N. (1979) Water stress responses of apple trees. I. Effects of light and soil preconditioning treatments on tree physiology. Journal of the American Society for Horticultural Science, Vol.104, pp. 392-395, ISSN 0003-1062

DeBano, L.F. (2000) Water repellency in soils: A historical overview. Journal of Hydrology, Vol.231-232, pp. 4-32, ISSN 0022-1694 
Edstrom, J. \& Schwankl, L. (2004) Nickels Soil Lab Project, In: Years of Discovery. A Compendium of Production and Environmental Research Projects, 1972-2003, pp. 337346, California Almond Board, Modesto, California, USA

Fereres, E., Martinich, D., Aldrich, T., Castel, J., Holzapfel, E. \& Schulbach, H. (1982) Drip irrigation saves money in a young almond orchard. California Agriculture, Vol. 36, pp. 12-13, ISSN 0008-0845

Hess, M., Strik, B., Smesrud, J. \& Selker, J. (2000) Blueberry, In: Western Oregon Irrigation Guides, pp. 11-12, Oregon State University Extension Service, EM 8713, Corvallis, Oregon, USA

Hicklenton, P.R., Reekie, J.Y., Gordon, R.J. \& Percival D.C. (2000) Seasonal patterns of photosynthesis and stomatal conductance in lowbush blueberry plants managed in a two-year production cycle. HortScience, Vol.35, pp. 55-59, ISSN 0018-5345

Holzapfel, E.A., Hepp, R.F. \& Mariño M.A. (2004) Effect of irrigation on fruit production in blueberry. Agricultural Water Management, Vol.67, pp. 173-184, ISSN 0378-3774

Krewer, G., Ruter, J., NeSmith, D.S., Clark, J., Otts, T., Scarborough, S. \& Mullinix, B. (2002) Performance of low cost organic materials as blueberry substrates and soil amendments. Acta Horticulturae, Vol.574, pp. 273-279, ISSN 0567-7572

Kruse, E.G., Bucks, D.A. \& von Bernuth R.D. (1990) Comparison of irrigation systems, In: Irrigation of Agricultural Crops, B.A. Stewart \& D.R. Nielson (eds.), pp. 475-508, Agronomy Monograph No. 30, American Society of Agronomy, Inc. Publishers, ISBN 0-89118-102-4, Madison, Wisconsin, USA

Mingeau, M., Perrier, C. \& Améglio, T. (2001) Evidence of drought-sensitive periods from flowering to maturity on highbush blueberry. Scientia Horticulturae, Vol.89, pp. 2340, ISSN 0304-4238

Nightingale, G.T. (1935) Effects of temperature on growth, anatomy, and metabolism of apple and peach roots. Botanical Gazette, Vol.96, pp. 58-637, ISSN 0006-8071

Patten, K.D., Neuendorff, E.W., \& Peters, S.C. (1988) Root distribution of 'Climax' rabbiteye blueberry as affected by mulch and irrigation geometry. Journal of the American Society for Horticultural Science, Vol.113, pp. 657-661, ISSN 0003-1062

Pearcy, R.W., Schulze, E.-D. \& Zimmermann, R. (1989) Measurements of transpiration and leaf conductance, In: Plant Physiological Ecology. Field Methods and Instrumentation, R.W. Pearcy, J. Ehleringer, H.A. Mooney \& P.W. Rundel (eds.), Chapman and Hall, ISBN 0-412-40730-2, New York, New York, USA

Renquist, A.R, Breen, B.J. \& Martin, L.W. (1982) Influences of water status and temperature on leaf elongation in strawberry. Scientia Horticulturae, Vol.18, pp. 77-85, ISSN 03044238

Rogers, W.S. (1939) Root studies: VIII. Apple root growth in relation to rootstock, soil, seasonal, and climatic factors. Journal of Pomology and Horticultural Science, Vol.17, pp. 99-130, ISSN 0028-0836

Savé, R., Peñuelas, J., Marfà, O. \& Serrano, L. (1993) Changes in leaf osmotic and elastic properties and canopy structure of strawberries under mild water stress. HortScience, Vol.28, pp. 925-927, ISSN 0018-5345

Scholander, P.F., Hammel, H.T., Hemmingsen, E.A. \& Bradstreet, E.D. (1964) Hydrostatic pressure and osmotic potential in leaves of mangrove and some other plants. Proceedings of the National Academy of Sciences, USA, Vol.52, pp. 119-125, ISSN 00278424 
Shackel, K.A., Ahmadi, H., Biasi, W., Buchner, R., Goldhamer, D., Gurusinghe, S., Hasey, J., Kester, D., Krueger, B., Lampinen, B.B., McGourty, G., Micke, W., Mitcham, E., Olsen, B., Pelletrau, K., Phillips, H., Ramos, D., Schwankl, L., Sibbert, S., Snyder, R., Southwick, S., Stevenson, M., Thorpe, M., Weinbaum, S. \& Yeager, J. (1997) Plant water status as an index of irrigation need in deciduous fruit trees. HortTechnology Vol.7, pp. 23-29, ISSN 1063-0918

Slayter, R.O. (1967) Plant-Water Relationships. Academic Press, New York, New York, USA

Sperry, J.S., Donnelly, R.R. \& Tyree, M.T. (1988) A method for measuring hydraulic conductivity and embolism in xylem. Plant, Cell E Environment, Vol.11, pp. 35-40, ISSN 0140-7791

Strik, B. \& Buller, G. (2005) The impact of early cropping on subsequent growth and yield of highbush blueberry in the establishment years at two planting densities is cultivar dependent. HortScience, Vol.40, pp. 1998-2001, ISSN 0018-5345

Strik, B. \& Yarborough, D. 2005. Blueberry production trends in north america, 1992 to 2003 and predictions for growth. HortTechnology Vol.15, pp. 391-398, ISSN 1063-0918

Strik, B., Brun, C., Ahmedullah, M., Antonelli, A., Askam, L., Barney, D., Bristow, P., Fisher, G., Hart, J., Havens, D., Ingham, R., Kaufman, D., Penhalgon, R., Pscheidt, J., Scheer, B., Shanks, C. \& William, R. (1993) Highbush Blueberry Production. Oregon State University Extension Service Publication PNW 215

Tamada, T. (2002) Stages of rabbiteye and highbush blueberry fruit development and associated changes in mineral elements. Acta Horticulturae, Vol.574, pp. 129-137, ISSN 0567-7572

Throop, P.A. \& Hanson, E.J. (1997) Effect of application date on absorption of ${ }^{15}$ nitrogen by highbush blueberry. Journal of the American Society for Horticultural Science, Vol.122, pp. 422-426, ISSN 0003-1062

USHBC (2009) 2009 World blueberry acreage and production report. U.S. Highbush Blueberry Council.

White, L.D. (2006) The effect of pre-plant incorporation with sawdust, sawdust mulch, and nitrogen fertilizer rate on soil properties and nitrogen uptake and growth of 'Elliott' highbush blueberry. MS Thesis, Oregon State University, Corvallis, Oregon, USA

Zhang, B. \& Archbold, D.D. (1993) Solute accumulation in leaves of a Fragaria chiloensis and a F. virginiana responds to water deficit stress. Journal of the American Society for Horticultural Science, Vol.118, pp. 280-285, ISSN 0003-1062 


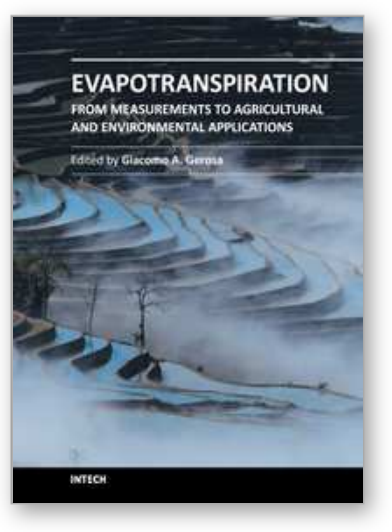

\section{Evapotranspiration - From Measurements to Agricultural and Environmental Applications}

Edited by Dr. Giacomo Gerosa

ISBN 978-953-307-512-9

Hard cover, 410 pages

Publisher InTech

Published online 09, November, 2011

Published in print edition November, 2011

This book represents an overview of the direct measurement techniques of evapotranspiration with related applications to the water use optimization in the agricultural practice and to the ecosystems study. Different measuring techniques at leaf level (porometry), plant-level (sap-flow, lysimetry) and agro-ecosystem level (Surface Renewal, Eddy Covariance, Multi layer BREB), are presented with detailed explanations and examples. For the optimization of the water use in agriculture, detailed measurements on transpiration demands of crops and different cultivars, as well as results of different irrigation schemes and techniques (i.e. subsurface drip) in semi-arid areas for open-field, greenhouse and potted grown plants are presented. Aspects on ET of crops in saline environments, effects of ET on groundwater quality in xeric environments as well as the application of ET to climatic classification are also depicted. The book provides an excellent overview for both, researchers and student,s who intend to address these issues.

\section{How to reference}

In order to correctly reference this scholarly work, feel free to copy and paste the following:

David R. Bryla (2011). Crop Evapotranspiration and Irrigation Scheduling in Blueberry, Evapotranspiration From Measurements to Agricultural and Environmental Applications, Dr. Giacomo Gerosa (Ed.), ISBN: 978953-307-512-9, InTech, Available from: http://www.intechopen.com/books/evapotranspiration-frommeasurements-to-agricultural-and-environmental-applications/crop-evapotranspiration-and-irrigationscheduling-in-blueberry

\section{INTECH}

open science | open minds

\section{InTech Europe}

University Campus STeP Ri

Slavka Krautzeka 83/A

51000 Rijeka, Croatia

Phone: +385 (51) 770447

Fax: +385 (51) 686166

www.intechopen.com

\section{InTech China}

Unit 405, Office Block, Hotel Equatorial Shanghai

No.65, Yan An Road (West), Shanghai, 200040, China

中国上海市延安西路65号上海国际贵都大饭店办公楼 405 单元

Phone: +86-21-62489820

Fax: $+86-21-62489821$ 
(C) 2011 The Author(s). Licensee IntechOpen. This is an open access article distributed under the terms of the Creative Commons Attribution 3.0 License, which permits unrestricted use, distribution, and reproduction in any medium, provided the original work is properly cited. 